\title{
Desain Buku Ajar Matematika Bilingual Materi Bangun Datar MEnggunakan PENDEKatan PMRI BERKonteks KEBUDAYAAN LOKAL
}

\author{
Lisnani $^{*}{ }^{\text {dan Sheilla Noveta Asmaruddin }}{ }^{2}$ \\ 1Pendidikan Guru Sekolah Dasar, Universitas Katolik Musi Charitas \\ Jl. Bangau No 60, Palembang, Sumatera Selatan, Indonesia \\ Lisnanipcmtk@yahoo.com \\ ${ }^{2}$ Pendidikan Guru Sekolah Dasar, Universitas Katolik Musi Charitas \\ Jl. Bangau No 60, Palembang, Sumatera Selatan, Indonesia
}

Artikel diterima: 1 Agustus 2018, direvisi: 5 September 2018, diterbitkan: 30 September 2018

\begin{abstract}
Abstrak
Pembelajaran matematika merupakan pembelajaran dari sesuatu yang bersifat konkret menuju abstrak. Hal ini sejalan dengan materi bangun datar yang cenderung abstrak. Namun, pada kenyataannya cara pemikiran siswa bersifat konkret. Maka dari itu, untuk menjembataninya diperlukan pendekatan yang mengutamakan pembelajaran yang bersifat konkret yaitu pendekatan PMRI (Pendidikan Matematika Realistik Indonesia). Pendekatan ini dilakukan dengan cara mendesain buku ajar bilingual berkonteks kebudayaan lokal melalui serangkaian aktivitas pembelajaran bangun datar menggunakan pendekatan PMRI. Penelitian ini merupakan penelitian design research yang terdiri dari tiga tahap yaitu preliminary design, the design experiment, dan retrospective analysis. Penelitian ini bertujuan menghasilkan lintasan belajar menggunakan buku ajar bilingual materi bangun datar. Pengumpulan data menggunakan lembar observasi, wawancara, dan lembar aktivitas siswa. Data dianalisis menggunakan lembar validasi dari ahli. Hasil analisis menunjukkan bahwa penggunaan buku ajar bilingual ini dapat meningkatkan pemahaman konsep siswa tentang bangun datar dari tahap informal ke tahap formal.

Kata Kunci: design research, PMRI, buku ajar bilingual, dan kebudayaan lokal.
\end{abstract}

\footnotetext{
Abstract (Bilingual Mathematics Textbook Design of Flat Building Topic Using Local Cultural Context PMRI Approach)

Learning mathematics is a learning deriving from abstract towards concrete similarly to twodimensional figure material. However, based on facts, the students' thinking-process is concrete, which is abstract. Hence, to connect them, it is advisable to prioritize concrete learning. That is through Indonesia Realistic Mathematics Education (PMRI) approach by designing a bilingual Mathematics textbook based on local cultural context. This research is a design research consisting of three steps. There are preliminary design, the design experiment, and the retrospective analysis. The aim of the research produced a bilingual textbook in which the material focused on two-dimensional figure. Data collection by using observation sheet, interviews, and students' worksheet. The data analysis by using validation sheet from the expert. The research is that the use of bilingual textbook using PMRI approach is able to improve the students' concept understanding in two-dimensional figure from informal to formal step.

Keyword: design research, PMRI, bilingual text book, and local cultural.
} 


\section{Pendahuluan}

Pada tahun 2003, pemerintah pernah berupaya untuk meningkatkan kualitas Undang-Undang (UU) Nomor 20 Pasal 50 ayat 3 melalui Menteri Pendidikan Nasional. Isi dari UU menetapkan suatu program pendidikan yaitu Rintisan Sekolah Bertaraf Internasional (RSBI) dengan harapan dapat menciptakan sekolah yang berkualitas dan penggunaan bilingual (dua bahasa) di dalam pembelajaran. Awal pelaksanaan program ini sangat menarik perhatian masyarakat karena sebagian sekolah menggunakan bahasa Inggris sebagai bahasa pengantar. Namun, sebagian sekolah juga ada yang menyalahgunakan program ini sehingga program ini ditarik oleh Menteri.

Namun, pada kenyataannya berdasarkan hasil wawancara dengan Wakil Kepala SMP Negeri 1 Palembang Bidang Kesiswaan menjelaskan bahwa "program pembelajaran bilingual sangat berguna bagi siswa di dalam pembelajaran walaupun sudah banyak sekolah yang meninggalkan program pembelajaran bilingual ini". Akan tetapi, sekolah kami masih meneruskan program ini tujuannya ajang olimpiade matematika khususnya". Berdasarkan hasil wawancara yang dilakukan, terbukti bahwa sekolah ini masih membutuhkan penggunaan pembelajaran bilingual terutama pada mata pelajaran Matematika. pendidikan di Indonesia sesuai dengan siswa kami bisa bersaing terutama saat

Di samping itu, rendahnya mutu pendidikan di Indonesia khususnya pada mata pelajaran Matematika ditandai dengan menurunnya nilai UN Matematika SMP tahun ajaran 2016/2017 dengan penurunan mencapai 4,36 poin menjadi dasar menurunnya pemahaman konsep siswa. Sedangkan dipahami bahwa tujuan pembelajaran matematika menurut Kurikulum 2013 menekankan pada dimensi pedagogik modern dalam pembelajaran, yaitu menggunakan pendekatan scientific (ilmiah). Dalam pembelajaran matematika kegiatan yang dilakukan agar pembelajaran bermakna yaitu mengamati, menanya, mencoba, menalar, menyaji, dan mencipta (Fuadi, dkk. 2016: 47).

Matematika menuntut pula kemampuan berpikir eksploratif dan kreatif. Seseorang harus mengenali dan memahami peran yang dimainkan matematika dalam kehidupan, mampu mengambil keputusan dengan dasar yang kuat dan memanfaatkan matematika sehingga menjadi berguna (Rahayu, dkk., 2008). Tapi, pada kenyataannya pada pembelajaran matematika terdapat beberapa pokok bahasan yang menjadi kesulitan siswa salah satunya adalah materi bangun datar. Bangun datar merupakan materi yang cenderung abstrak karena soal-soal yang diberikan berbentuk pemecahan masalah sehingga dibutuhkan pemahaman konsep siwa yang menyeluruh pada materi bangun datar.

Bangun datar terdiri dari bangun datar sisi datar dan sisi lengkung. Bangun datar 
sisi datar terdiri dari segitiga dan segiempat. Menurut Suharjana (2008: 3), segiempat sebarang sebagai bangun datar bersisi empat yang tertutup dan sederhana. Sedangkan bangun datar sisi lengkung yaitu lingkaran.

Untuk mengatasi permasalahan siswa pada materi bangun datar diperlukan perbaikan kurikulum khususnya pada pelajaran matematika perlu dilakukan penyajian materi pada bahan ajar yang berbentuk buku ajar siswa. Buku yang digunakan hendaknya berbeda dengan buku-buku pada umumnya difokuskan kepada aplikasi dalam kehidupan seharihari yang dekat dengan lingkungan sekitar siswa (dunia real), materi yang disajikan merupakan masalah-masalah kontekstual dengan mempresentasikan pada semua level dari tujuan belajar matematika (level rendah, sedang dan tinggi), menggunakan dua bahasa (bilingual).

Menurut Mintowati (2003), buku ajar merupakan salah satu sarana keberhasilan proses belajar mengajar suatu kesatuan unit pembelajaran yang berisi informasi, pembahasan serta evaluasi. Buku ajar merupakan sumber belajar yakni, segala sesuatu yang memudahkan peserta didik memperoleh sejumlah informasi pengetahuan, pengalaman dan keterampilan dalam proses belajar mengajar (Adawiyah, 2015).

Buku ajar harus memiliki karakteristik buku yang menarik dan memuat aspek yang berpusat pada siswa sehingga interaktif, sehingga dengan buku ajar siswa dapat berdiskusi dengan kelompok, memecahkan masalah, dan memiliki materi yang berkaitan dengan kehidupan sehari-hari (Adisendjaja, 2007).

Permasalahan pembelajaran matematika yang cenderung bersifat abstrak dapat diatasi melalui pendekatan pembelajaran yang mampu menyajikan suatu pembelajaran yang nyata dan kontekstual salah satunya pendekatan Pendidikan Matematika Realistik Indonesia (PMRI) di dalam pendesainan buku ajar bilingual tersebut. PMRI menggunakan masalah kontekstual sebagai titik awal pengajaran matematika dan harus dihubungkan dengan kenyataan, berada dekat dengan peserta didik, dan relevan dengan kehidupan masyarakat agar memiliki nilai manusiawi (Depdiknas, 2005:29). PMRI dalam memulai pembelajaran menggunakan fenomena dan aplikasi yang nyata terhadap siswa, masalah yang diberikan merupakan masalah kontekstual.

Menurut de Lange, Teffers, Gravemeijer (Zulkardi, 2009) teori PMRI mempunyai lima karakteristik: 1) Menggunakan masalah kontekstual; 2) Menggunakan model atau jembatan sebagai instrumen vertikal; 3) Menggunakan kontribusi siswa; 4) Interaktivitas; 5) Terintegrasi dengan topik pembelajaran lainnya. Di dalam pendekatan PMRI sangat mengutamakan konteks di dalam pembelajarannya. Seperti pada penelitian Sarumaha (2018), berbagai konteks digunakan dalam rangkaian aktivitas pembelajaran pada materi persen. 
http://journal.institutpendidikan.ac.id/index.php/mosharafa

\begin{abstract}
Adapun konteks yang digunakan dalam buku ajar bilingual ini adalah konteks kebudayaan lokal. Materi bangun datar didesain menggunakan konteks kebudayaan lokal berupa rumah adat, bangunan bersejarah, benda-benda yang lain yang ada di Palembang seperti rumah Limas, songket, museum, kantor gubernur, dan lainnya. Tujuan dari penggunaan konteks kebudayaan lokal ini adalah agar dapat menjadikan materi bangun datar ini menjadi lebih nyata terutama dalam bentuk soal pemecahan masalah.
\end{abstract}

Maka dari itu, peneliti tertarik mendesain buku ajar matematika bilingual materi bangun datar menggunakan pendekatan PMRI untuk meningkatkan pemahaman konsep siswa tentang bangun datar. Penelitian seperti ini juga pernah dilakukan oleh peneliti sebelumnya antara lain: 1) Ullya, dkk (2010) tentang "Desain Bahan Ajar Penjumlahan Pecahan Berbasis Pendidikan Matematika Realistik Indonesia (PMRI) untuk Siswa Kelas IV Sekolah dasar negeri 23 indralaya". Diperoleh hasil penelitian yaitu desain Bahan ajar penjumlahan pecahan berbasis PMRI untuk siswa kelas IV sudah dinyatakan baik, dilihat dari hasil ulangan harian siswa dari 4 soal yang diberikan untuk 49 orang ternyata untuk soal nomor 1 yang dinyatakan berhasil sebanyak 48 orang $(97,96 \%)$, soal nomor 2 yang dinyatakan berhasil 42 orang $(85,71 \%)$, soal nomor 3 yang dinyatakan berhasil sebanyak 32 orang $(65,31 \%)$, dan soal nomor 4 yang berhasil sebanyak 41 orang $(83,67 \%)$, dari keempat soal tersebut secara klasikal 348 menunjukkan 41 orang $(83,67 \%) ; 2)$

Simanulang (2016) tentang "Pengembangan Bahan Ajar Materi Himpunan Konteks Laskar Pelangi Dengan Pendekatan Pendidkan Matematika Realistik Indonesia (PMRI) Kelas VII Sekolah Menengah Pertama". Diperoleh hasil penelitian yaitu: (1) menghasilkan produk bahan ajar berupa LKS materi himpunan konteks Laskar Pelangi yang dikembangkan dengan pendekatan PMRI dengan dikategori valid dan praktis; (2) bahan ajar yang dikembangkan memiliki efek potensial terhadap hasil belajar siswa kelas VII SMP Negeri 4 Pangkal Pinang Bangka Belitung.

Adapun yang menjadi perbedaan penelitian ini dengan penelitian sebelumnya adalah penelitian ini mendesain buku ajar bilingual (dua bahasa) yaitu bahasa Indonesia dan bahasa Inggris dengan pokok bahasan bangun datar menggunakan konteks kebudayan lokal. Di samping itu, penelitian ini menggambarkan serangkaian aktivitas pembelajaran yang dideskripsikan melalui HLT (Hypothetical Learning Trajectory), yaitu dugaan rangkaian aktivitas pembelajaran (Afriansyah, 2017), pada tahapan pilot experiment dan LIT (Local Instructional Theory) pada tahapan teaching experiment yang pada akhirnya akan menghasilkan lintasan belajar/ LT (Learning Trajectory)

HLT sebagai gambaran proses pembelajaran ketika siswa mengalami proses pembelajaran mulai dari awal sampai tercapainya tujuan pembelajaran. Mosharafa: Jumal Pendidikan Matematika Volume 7, Nomor 3, September 2018 Copyright $\odot 2018$ Mosharafa: Jurnal Pendidikan Matematika 
HLT didesain berdasarkan tujuan pembelajaran yang ingin dicapai, aktivitas, dan hipotesis matematis berupa konjektur yang diharapkan terjadi pada siswa sesuai dengan kemampuan berpikirnya (Sztajn et.al, 2012). Oleh karena itu, di dalam penyusunan HLT perlu diperhatikan tahap alur pikir siswa dan konsep materi yang harus dibangun bagi siswa (Fuadiah, 2017).

Menurut Gravemeijer (2004), HLT terdiri dari tiga komponen:

1. Tujuan pembelajaran matematika bagi peserta didik.

2. Aktivitas pembelajaran dan konteks yang digunakan dalam proses pembelajaran.

3. Konjektur proses pembelajaran bagaimana mengetahui pemahaman dan strategi siswa yang muncul dan berkembang ketika aktivitas pembelajaran dilakukan di kelas.

Menurut Gravemeijer dan Cobb (2006:21), LIT adalah suatu teori yang terdiri dari dugaan mengenai proses pembelajaran siswa yang mungkin dilengkapi dengan dugaan mengenai alat bantu yang mendukung proses pembelajaran tersebut.

Adapun rumusan masalah dalam penelitian ini adalah: 1) bagaimana gambaran lintasan belajar melalui penggunaan buku ajar bilingual materi bangun datar?; 2) Bagaimana peningkatan pemahaman konsep siswa kelas VII melalui penggunaan buku ajar bilingual?

Tujuan dari penelitian ini adalah:1) menghasilkan lintasan belajar berupa HLT dan LIT yang terdiri dari serangkaian aktivitas melalui penggunaan buku ajar bilingual materi bangun datar menggunakan pendekatan PMRI; 2) meningkatkan pemahaman konsep siswa SMP Kelas VII melalui penggunaan buku ajar bilingual.

\section{Metode}

Penelitian ini dilakukan di SMP Negeri 1 Palembang pada tahun pelajaran 2017/2018, dengan sampel penelitian adalah kelas VII.7 yang berjumlah 6 orang dan seluruh siswa kelas VII.9 berjumlah 29 orang. Sedangkan teknik pengumpulan data dalam penelitian ini terdiri dari wawancara, observasi, teknik tertulis dalam bentuk tes (terdiri dari pretest dan posttest), dan dokumentasi (terdiri dari kamera video statis dan dinamis). Teknik analisa data berupa penggunaan lembar validasi yang dilakukan oleh expert terhadap buku ajar bilingual yang didesain oleh peneliti dan gambaran serangkaian aktivitas siswa pada proses pembelajaran tersebut.

Penelitian ini menggunakan metode design research merupakan salah satu bentuk pendekatan kualitatif. Design research mengandung pengertian suatu kajian sistematis yang merancang, mengembangkan, dan mengevaluasi intervensi pendidikan (berupa program, strategi, bahan pembelajaran, produk, dan sistem) sebagai solusi untuk memecahkan masalah yang kompleks dalam praktek pendidikan (Plomp \& Nieven, 2007:13). Design research bertujuan untuk 
mengembangkan LIT yang didasarkan pada teori yang sudah ada dan berdasarkan percobaan secara empirik melalui kerjasama antara peneliti dan guru yang bertujuan untuk meningkatkan relevansi penelitian dengan adanya kebijakan dan praktik pendidikan (Gravemeijer \& Van Erde, 2009).

Menurut Prahmana (2017: 13), design research merupakan suatu metode penelitian yang bertujuan mengembangkan LIT dengan kerjasama antara peneliti dan tenaga pendidik untuk meningkatkan kualitas pembelajaran. Sederetan aktivitas siswa terdiri dari konjektur strategi dan pemikiran siswa telah dikembangkan dalam penelitian ini. Dalam penelitian ini, peneliti mendesain aktivitas - aktivitas yang berdasarkan pengalaman siswa yaitu aktivitas yang erat dengan keseharian siswa sebagai suatu pendekatan untuk memahami konsep bangun datar.

Ada 3 tahap dalam design research (Gravemeijer and Cobb, 2006:19; Bakker, 2004) yaitu:1) Tahap 1: Preparing for the experiment/ preliminary design; 2) Tahap 2: The design experiment; 3) Tahap 3: The retrospective analysis.

\section{Hasil dan Pembahasan}

\section{A. Hasil Penelitian}

Pada tahap awal penelitian di tahapan pilot experiment, peneliti mendesain HLT tentang materi bangun datar melalui penggunaan buku ajar bilingual seperti pada Gambar 1.

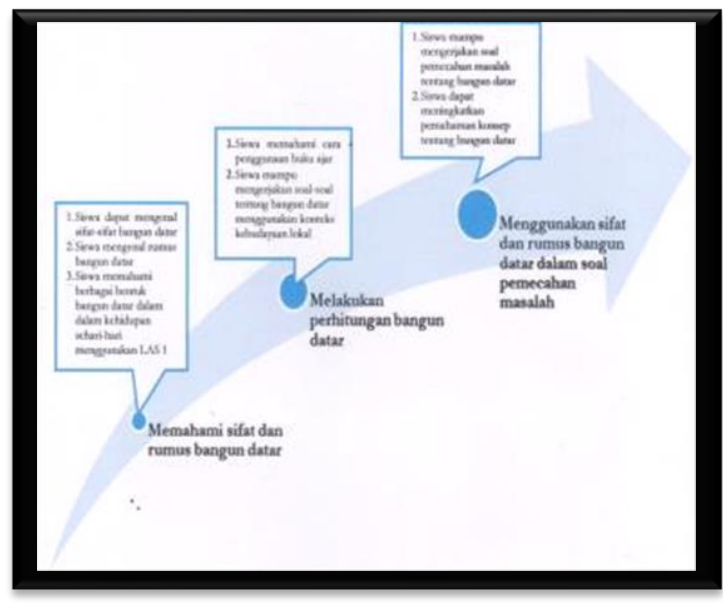

Gambar 1. HLT buku ajar bilingual materi bangun datar.

Setelah HLT didesain, maka akan disesuaikan dengan kondisi di sekolah pada saat dilakukan uji coba sehingga dihasilkan lintasan belajar (Learning Trajectory/LT) dari pembelajaran tentang bangun datar. Setelah selesai mendesain HLT, lalu dilakukan uji coba yang disesuaikan dengan kondisi di lapangan pada tahapan teaching experiment sehingga diperoleh LIT seperti Gambar 2.

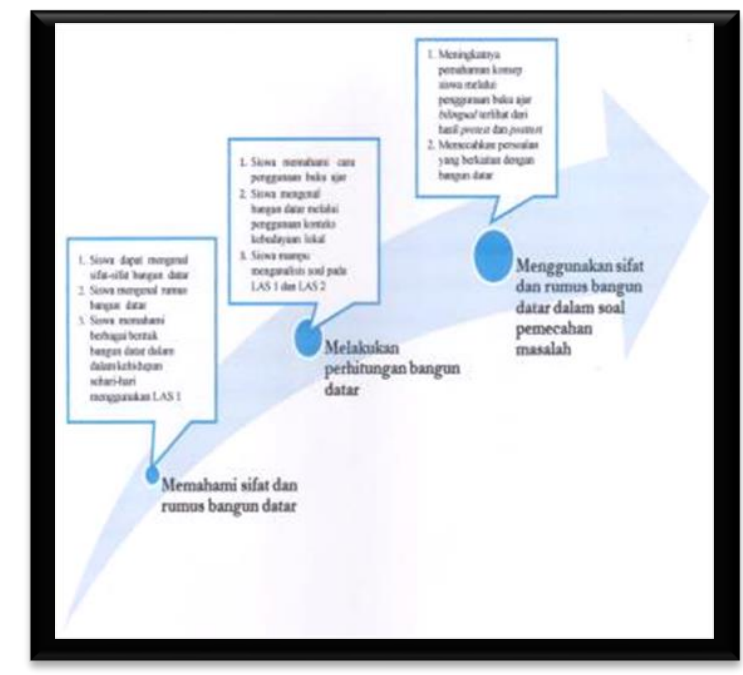

Gambar 2. LIT buku ajar bilingual materi bangun datar. 
Perbedaan HLT dan LIT terletak pada tahap akhir di HLT yang bertujuan mengetahui peningkatan pemahaman konsep siswa dalam menyelesaikan berbagai persolan pemecahan masalah. Selanjutnya, diperoleh learning trajectory yang didesain pada pembelajaran tentang bangun datar. Aktivitas pembelajaran dibagi dua aktivitas untuk meningkatkan pemahaman konsep tentang bangun datar seperti pada Gambar 3.

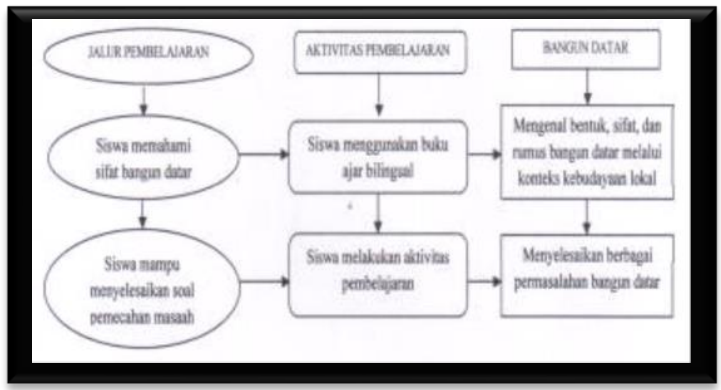

Gambar 3. LT buku ajar bilingual materi bangun datar.

Di samping menghasilkan lintasan belajar, penelitian ini juga menghasilkan buku ajar bilingual tentang materi bangun datar yang valid dan praktis seperti Gambar 4.

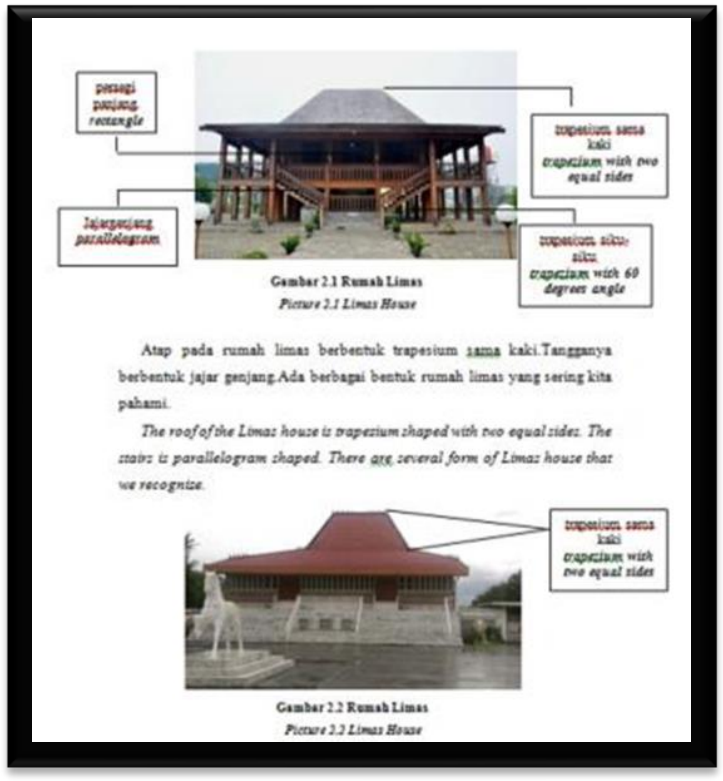

Gambar 4. Buku ajar bilingual materi bangun datar.

Teknik analisa data berupa uji validitas menggunakan validasi ahli dalam bentuk instrument validasi kepada validator dengan aspek yang dinilai dalam lembar instrumen validasi buku ajar. Kegiatan validasi diawali dengan memberikan produk buku ajar beserta lembar penilaian kepada 3 orang ahli. Sehingga diperoleh rangkuman hasil penilaian buku ajar oleh validator ahli pada Tabel 1.

Tabel 1.

Rangkuman hasil penilaian buku ajar oleh validator

\begin{tabular}{clc|}
\hline Aspek buku ajar & $\begin{array}{c}\text { Rata-rata } \\
\text { penilaian }\end{array}$ & Ket \\
\hline Kelayakan isi & 4,2 & $\mathrm{~V}$ \\
\hline Penyajian & 4,3 & $\mathrm{~V}$ \\
\hline Kebahasaan & 4,0 & $\mathrm{~V}$ \\
\hline Kegrafisan & 4,5 & $\mathrm{~V}$ \\
\hline Rata-rata total & 4,25 & $\mathrm{~V}$
\end{tabular}

Tabel 1 menunjukkan nilai rata-rata kevalidan seluruh aspek buku ajar dari segi isi, penyajian, kebahasaan, dan kegrafisan buku ajar ini secara keseluruhan dapat 
dikatakan valid (nilai rata-rata total 4,25). Namun demikian, beberapa komponen buku ajar masih perlu diperbaiki/ditambah, sesuai saran dari ahli.

Di samping melakukan uji validitas, peneliti juga membagikan angket kepada siswa untuk mengetahui respon siswa terhadap buku ajar ini seperti Tabel 2.

Tabel 2.

Hasil Respon Siswa

\begin{tabular}{|cc|}
\hline Kriteria & $\begin{array}{c}\text { Rata-rata } \\
\text { penilaian }\end{array}$ \\
\hline Sangat Baik & $30,62 \%$ \\
\hline Baik & $52,32 \%$ \\
\hline Cukup Baik & $15,19 \%$ \\
\hline Kurang Baik & $1,87 \%$ \\
\hline Tidak Baik & $0 \%$ \\
\hline
\end{tabular}

Di samping itu, untuk mengetahui peningkatan pemahaman konsep siswa setelah menggunakan buku ajar bilingual dilakukan pretest dan posttest kelas VII.9 dengan menggunakan uji independent sample t-test seperti Tabel 3.

Tabel 2.

Hasil Pretest dan Posttest Kelas VII.9

\begin{tabular}{cccccc}
\multicolumn{4}{c}{ One-Sample Statistics } \\
\hline & & & & \multicolumn{1}{c}{ Std. } \\
& & N & Mean & Deviation & \multicolumn{1}{c}{$\begin{array}{c}\text { Error } \\
\text { Mean }\end{array}$} \\
\hline Pemahaman & pretest & 29 & 54.08 & 7.709 & 1.285 \\
konsep & posttest & 29 & 79.53 & 17.313 & 2.885 \\
\hline
\end{tabular}

One-Sample Test

\begin{tabular}{|c|c|c|c|c|c|c|}
\hline & \multicolumn{6}{|c|}{ Test Value $=0$} \\
\hline & \multirow[b]{2}{*}{$\mathrm{T}$} & \multirow[b]{2}{*}{ Df } & \multirow{2}{*}{$\begin{array}{l}\text { Sig. (2- } \\
\text { tailed) }\end{array}$} & \multirow{2}{*}{$\begin{array}{c}\text { Mean } \\
\text { Differenc } \\
\text { e }\end{array}$} & \multicolumn{2}{|c|}{$\begin{array}{l}\text { 95\% Confidence } \\
\text { Interval of the } \\
\text { Difference }\end{array}$} \\
\hline & & & & & Lower & Upper \\
\hline Pretest & 41.295 & 29 & .000 & 53.056 & 50.45 & 55.66 \\
\hline posttest & 27.224 & 29 & .000 & 78.556 & 72.70 & 84.41 \\
\hline
\end{tabular}

Tabel 3 menunjukkan hasil nilai pretest dan posttest sebelum dan sesudah menggunakan buku ajar bilingual mengalami peningkatan pemahaman konsep dari 54,08 menjadi 79,53 dan terdapat perbedaan nilai pretest dan posttest.

\section{B. Pembahasan}

Serangkaian aktivitas pembelajaran digambarkan melalui HLT pada tahapan pilot experiment dan LIT pada tahapan teaching experiment dideskripsikan sebagai berikut:

Aktivitas 1: Lembar Aktivitas Siswa (LAS) menggunakan pendekatan PMRI

Tujuan Aktivitas 1: mengenal sifat-sifat bangun datar

\section{Deskripsi Aktivitas 1:}

Pada tahap awal, guru membagi siswa ke dalam kelompok dengan teman sebangkunya. Guru menggali pengetahuan awal siswa melalui lembar aktivitas siswa yang disediakan guru. Disini terlihat kemampuan siswa dalam bekerja sama dalam kelompoknya dalam mengerjakan lembar aktivitas siswa.

Pada aktivitas ini siswa bekerja sama dengan kelompoknya dalam menentukan sifat-sifat dari bangun datar menggunakan lembar aktivitas siswa 1 yang berisi pengenalan bangun datar menggunakan pendekatan PMRI. Lalu, siswa mengerjakan soal-soal yang ada di lembar aktivitas siswa (LAS).

\section{Hasil Kerja Peserta didik Pada Aktivitas 1}

Permasalahan yang dihadapi siswa pada aktivitas pertama adalah sebagian siswa

Mosharafa: Jumal Pendidikan Matematika Volume 7, Nomor 3, September 2018 Copyright $\odot 2018$ Mosharafa: Jurnal Pendidikan Matematika 
belum terbiasa belajar bangun datar menggunakan konteks berupa kebudayaan lokal yang menjadi bagian dari pendekatan PMRI. Dengan kata lain, siswa cenderung belajar bangun datar secara langsung berdasarkan gambar yang diberikan guru di kelas tanpa menggunakan konteks di dalam pembelajaran. Hal ini tentunya kurang menggali pemahaman siswa secara menyeluruh.

Siswa juga merasa kesulitan dalam mengerjakan soal-soal untuk menemukan sifat-sifat bangun datar salah satunya pada soal nomor 7 seperti Gambar 5 dan Gambar 6.

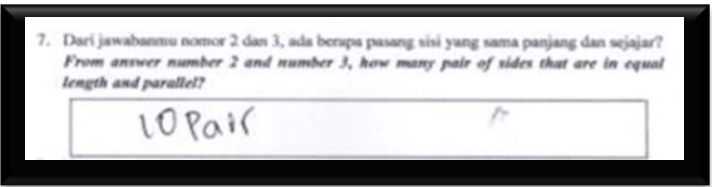

Gambar 5. Jawaban kelompok dari siswa F dan R pada pertanyaan nomor 7

Dari jowabanmu nomor 2 dan 3, adu berape pasung sisi yang sama panjang dan sejajar? From anser number 2 and number 3, how many pair of sides that are in cqual length and parallel?

8 buah, 4 posang

Gambar 6. Jawaban Nabila dan Andienda pada pertanyaan nomor 7

Berdasarkan Gambar 5 dan 6 siswa mempunyai pemahaman yang berbeda dalam menentukan jumlah sisi yang sama panjang dan sejajar. Walaupun apabila dijabarkan diperoleh jawaban yang berbeda dari kedua jawaban yang dijawab siswa seperti pada Gambar 7.

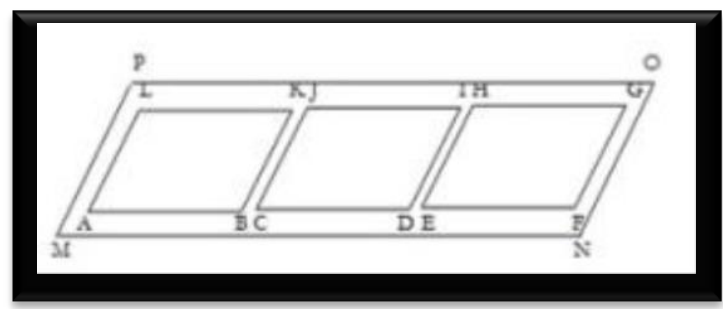

Gambar 7. Soal nomor 7 pada LAS 1

Pada gambar 6, diperoleh jawaban jumlah sisi yang sama panjang dan sejajar sebanyak 14 pasang terdiri dari $A B / / K L$, $\mathrm{CD} / / \mathrm{IJ}, \mathrm{EF} / / \mathrm{GH}$. AL//BK, CJ//DI, EH//FG, $\mathrm{MN} / / \mathrm{OP}, \mathrm{MP} / / \mathrm{NO}, \mathrm{AD} / / \mathrm{IL}, \mathrm{AL} / / \mathrm{DI}, \mathrm{CF} / / \mathrm{GJ}$, $\mathrm{CJ} / / \mathrm{FG}, \mathrm{AF} / / \mathrm{GL}$, dan AL//GF. Perbedaan jawabannya karena perbedaan cara berpikir siswa yang berbeda-beda.

Aktivitas 2: Penggunaan buku ajar bilingual berkonteks kebudayaan local

Tujuan Aktivitas 2: mampu menyelesaikan soal pemecahan masalah

Deskripsi Aktivitas 2:

Guru membagikan buku ajar bilingual lalu melakukan sesi tanya jawab. Selanjutnya, siswa diminta mengerjakan LAS 2 tentang soal pemecahan masalah (problem solving) seperti Gambar 8.

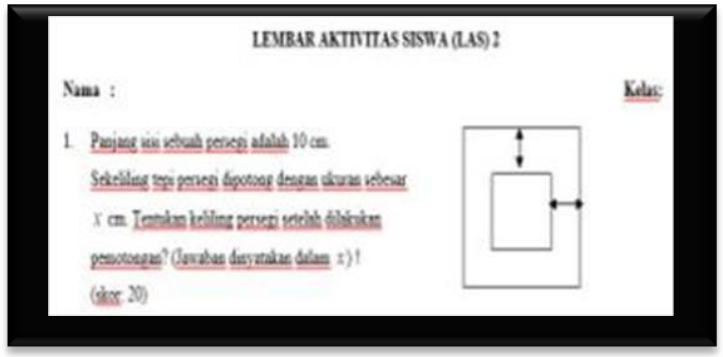

Gambar 8. Soal Nomor 1 LAS 2

Pada LAS 2 ini terlihat kemampuan pemecahan masalah siswa. Pada soal 
nomor 1, terdapat perbedaan jawaban siswa seperti Gambar 9 dan Gambar 10.

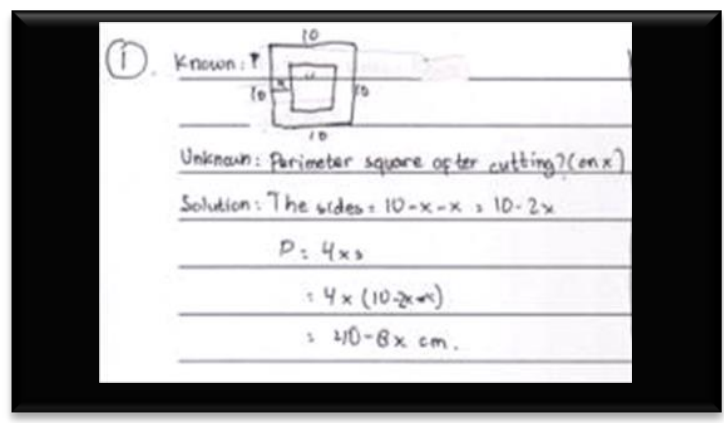

Gambar 9. Jawaban dari Siswa Berinisial BR

Gambar 9 menjelaskan bahwa cara berpikir siswa menggunakan pemisalan $\mathrm{x}$ dan menggunakan teknik kesebangunan antara persegi kecil dan persegi besar.

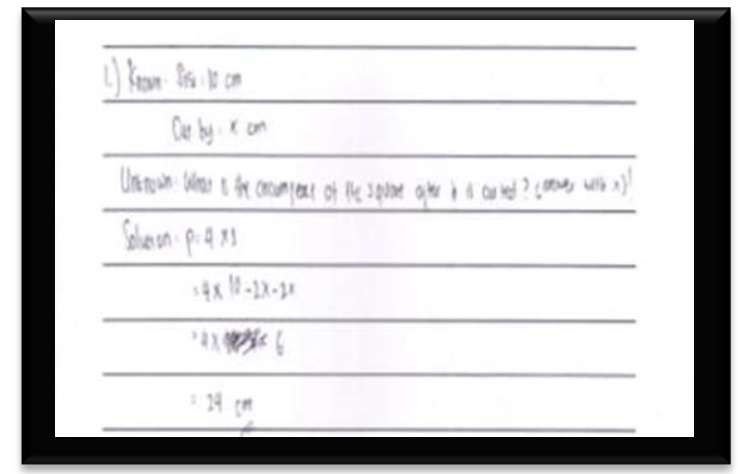

Gambar 10. Jawaban dari Siswa Berinisial IN

Gambar 10 menjelaskan bahwa cara berpikir siswa yang kurang tepat. Karena siswa menghitung menggunakan $2 x$ berkali-kali di dalam perhitungan.

Perbedaan jawaban siswa karena siswa belum memahami definisi sisi secara menyeluruh. Pada persegi perhitungan pengurangan sisi hanya pada salah satu sisi, sedangkan sisi lainnya hanya menyamakan sisi yang telah ditemukan.

\section{Penutup}

Berdasarkan hasil dan pembahasan yang telah dijelaskan, diperoleh kesimpulan dari penelitian ini yaitu dihasilkannya lintasan belajar yang sangat berguna di dalam pembelajaran tentang bangun datar melalui penggunaan buku ajar bilingual. Lintasan belajar membuat proses pembelajaran menjadi lebih teratur dan guru dapat mengatur keseluruhan aktivitas dalam pembelajaran. Lintasan belajar ini berisi tujuan pembelajaran dan aktivitas siswa yang telah disesuaikan dengan kondisi siswa di SMP Negeri 1 Palembang.

Buku ajar yang dihasilkan dapat dikatakan valid dan praktis berdasarkan uji validitas yang diberikan kepada guru matematika di sekolah dan beberapa masukan dari ahli (expert). Lintasan belajar yang dihasilkan sangat berguna di dalam pembelajaran tentang bangun datar. Melalui lintasan belajar ini pembelajaran menjadi lebih teratur dan guru dapat mengatur keseluruhan aktivitas dalam pembelajaran. Lintasan belajar ini berisi tujuan pembelajaran dan aktivitas siswa yang telah disesuaikan dengan kondisi siswa di SMP Negeri 1 Palembang.

Melalui penggunaan buku ajar ini, diperoleh meningkatnya kemampuan pemahaman konsep siswa secara menyeluruh tentang bangun datar. Hal ini terlihat dari kemampuan siswa dalam mengerjakan lembar aktivitas siswa tentang bangun datar. Sebagai tambahan, 354
Mosharafa: Jumal Pendidikan Matematika Volume 7, Nomor 3, September 2018 Copyright $\odot 2018$ Mosharafa: Jurnal Pendidikan Matematika 
pemahaman konsep siswa terlihat dari peningkatan hasil belajar berdasarkan nilai rata-rata posttest lebih baik daripada pretest siswa. Rata nilai hasil pretest sebesar 54,08 sedangkan posttest sebesar 79,53 . Peningkatan sebesar 25,45 terjadi setelah penggunaan buku ajar bilingual.

\section{Daftar PUstaka}

Adawiyah, R. (2015). Pengembangan Buku Ajar Biologi Bilingual SMA Kelas XI Semester 1. Prosiding Seminar Nasional Pendidikan Biologi 2015. Prodi Pendidikan Biologi FKIP Universitas Muhammadiyah Malang, tema: "Peran Biologi dan Pendidikan Biologi dalam Menyiapkan Generasi Unggul dan Berdaya Saing Global", $561-570$.

Adisendjaja, H.\&Yusuf. (2007). Analisis Buku Ajar Sains Berdasarkan Literasi Ilmiah Sebagai Dasar Untuk Memilih Buku Ajar Sains (biologi). Makalah disajikan pada Seminar Nasional Pendidikan Biologi dan Biologi di Jurusan Pendidikan Biologi FPMIPA UPI American Society for Training \& Development. 2007. Job Aid: ISD Models.

Afriansyah, E. A. (2017). Desain Lintasan Pembelajaran Pecahan melalui Pendekatan Realistic Mathematics Education. Mosharafa: Jurnal Pendidikan Matematika, 6(3), 463474.

Bakker, A. (2004). Design Research in Statistics Education on Symbolizing and Computer Tools. Amersfoort: Wilco Press.

Depdiknas. (2005). Pendekatan Pembelajaran Matematika. Materi Pelatihan Terintegrasi Matematika. Jakarta: Depdikbud.

Djaali. (2008). Pengukuran dalam Bidang Pendidikan. Jakarta: PT Gramedia Widiyasarana Indonesia.

Fuadi, R., dkk. (2016). Peningkatan Kemampuan Pemahaman dan Penalaran Matematis melalui Pendekatan Kontekstual. Jurnal Didaktika Matematika, 3(1), 47-54.

Fuadiah, N. F. (2017). Hypothetical Learning Trajectory pada Pembelajaran Bilangan Negatif Berdasarkan Teori Situasi Didaktis di Sekolah Menengah. Mosharafa: Jurnal Pendidikan Matematika, 6 (1), 13-24

Gravemeijer, K. \& van Erde, D. (2009). Design research as a means for building a knowlgde base for teachers and teaching in math education. The elementary School Journal, 109(5), 510-524.

Gravemeijer, Koeno, \& Cobb, Paul. (2006). Design Research from a Learning Design Perspective. New York: Routledge.

Plomp, T. \& Nieveen, N. (2007). An Introduction to Educational Design Research. Netherlands Institute: SLO.

Pramana, R.C.I., (2017). Design Research (Teori dan Implementasinya: Suatu Pengantar). Depok: Raja Grafindo Persada. 
Rahayu, T., dkk. (2008). Pengembangan Instrumen Penilaian Dalam Pendidikan Matematika Realistik Indonesia (PMRI) di SMP Negeri 17 Palembang. Jurnal Pendidikan Matematika, 2(2), 19-35.

Sarumaha, Y. A. Percentage Bar: A Model for Helping Fifth Grade Students Understand Percentages. Mosharafa: Jurnal Pendidikan Matematika. 7(2). 155-166.

Simanulang, J. (2013). Pengembangan Bahan Ajar Materi Himpunan Konteks Laskar Pelangi dengan Pendekatan Pendidikan Matematika Realistik Indonesia (PMRI) Kelas VII Sekolah Menengah Pertama. Jurnal Pendidikan Matematika, 7(2), 25-35.

Simon, M. A. (1995) Reconstructing mathematics pedagogy from a constructivist perspective. Journal for Research in Mathematics Education, 26, 114-145.

Sztajn, P., Confrey, J., Holt Wilson, P., dan Edgington, C. (2012). Learning trajectory based instruction: toward a theory of teaching. Educational Researcher, 41(5), 147-156.

Ullya, dkk. (2010). Desain Bahan Ajar Penjumlahan Pecahan Berbasis Pendidikan Matematikan Realistik Indonesia (PMRI) untuk Siswa Kelas VI Sekolah Dasar Negeri Indralaya. Jurnal Pendidikan Matematika, 4(2). 86-96. Zulkardi. (2009). The "P" in PMRI: Progress and Problems. ICMA Mathematic Education (pp. 773-780). Yogyakarta: IndoMS.

\section{Riwayat Hidup PENULIS}

Lisnani, S.Pd., M.Pd.

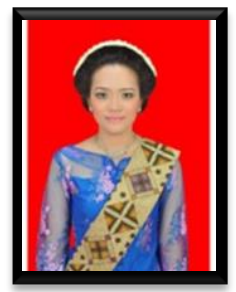

Lahir di Palembang, 19 September 1987. Sekretaris Program Studi PGSD di Universitas Katolik Musi Charitas. Studi: S1 Pendidikan Fisika di Universitas PGRI Palembang, tahun 2006 dan lulus tahun 2010; S2 Pendidikan Matematika di Universitas Sriwijaya Palembang, Sumatera Selatan. Pada tahun 2016 mengikuti SEMIRATA 2016 BIDANG MIPA BKS PTN BARAT Peran MIPA Dalam Meningkatkan Daya Saing Bangsa Menghadapi Masyarakat Ekonomi ASEAN; menjadi pemakalah pada The $1^{\text {st }}$ International Conference On Law, Economics, and Education "Building Mutually Beneficial Cooperation to Facing ASEAN Economic Community". Pada tahun 2017 menjadi pemakalah pada International Conference on Mathematic and Natural Science. Pada tanggal 5 Mei 2018 menjadi pemakalah pada International Conference on Mathematics and Sciences Education; mendapatkan Hibah Penelitian Dosen Pemula dari Ristekdikti dengan Judul "Desain Buku Ajar Matematika Bilingual Materi Bangun Datar Menggunakan Pendekatan PMRI"; bulan Juni 2017, hasil artikel peneliti tembus Scopus pada Jurnal IOP Conference Series.

Sheilla Noveta Asmaruddin, M.Ed. (TESOL).

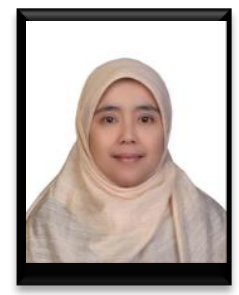

Lahir di Sydney, Australia, 20 November 1973. Dosen tetap di UNIKA Musi Charitas, Palembang. Studi: S1 Pendidikan Bahasa Inggris di Universitas Sriwijaya, Palembang tahun 2005 dan lulus tahun 2009; S2 Teaching English to Speakers of Other Languages di Queensland University of Technology, Brisbane pada tahun 2013 dan lulus tahun 2014. Tahun 2015 menjadi pembicara/penyaji makalah dalam pertemuan ilmiah Konferensi Internasional Asia TEFL yang ke-13 di Nanjing, China. 